\title{
A refração do realismo em Luiz Ruffato: um inferno permanente
}

\author{
Luiz Ruffato's Refraction of Realism: A Permanent Hell \\ La refracción del realismo de Luiz Ruffato: un infierno permanente
}

Tânia Pellegrini*

\section{Resumo}

De acordo com Bourdieu (1996), as representações são convenções de entendimento e modelagem das estruturas e relações sociais, além de práticas que atribuem sentidos ao real, com efeitos em sua construção. Considerando ainda o conceito de "realismo refratado" (Pellegrini, 2018), este artigo procura verificar como Inferno provisório, de Luiz Ruffato, representa, por meio do tratamento específico das categorias literárias, aspectos da sociedade brasileira, como a desigualdade e a exploração, combinadas com a modernização conservadora das últimas décadas, criando uma forma particular de captar a relação entre os indivíduos e a sociedade.

Palavras-chave: Luiz Ruffato, realismo, modernização, sociedade brasileira, êxodo rural.

\section{Abstract}

The essay has as its theoretical-critical basis the idea that representations are conventions for understanding and modeling social structures and relationships, as well as practices that assign meanings to the real, with effects on their construction (Bourdieu, 1996, p.107- 116). Considering also the concept of refracted realism (Pellegrini, 2018, p.17), we analyze how Luiz Ruffato's Inferno Provisório (2016) represents, through the specific treatment of literary categories, aspects of Brazilian society, such as inequality and exploitation combined with the conservative modernization of recent decades, creating a particular way of capturing the relationship between individuals and society.

Keywords: Luiz Ruffato, realism, modernization, Brazilian society, rural exodus.

\begin{abstract}
Resumen
De acuerdo con Bourdieu (1996), las representaciones son convenciones para comprender y modelar estructuras y relaciones sociales, así como prácticas que asignan significados a lo real, con efectos en su construcción. Considerando también el concepto de realismo refractado (Pellegrini, 2018), tratamos de verificar cómo Inferno provisorio, de Luiz Ruffato, representa, a través del tratamiento específico de categorías literarias, aspectos de la sociedad brasileña, como la desigualdad y la explotación, combinadas con la modernización conservadora de las últimas décadas, creando una forma particular de capturar la relación entre los individuos y la sociedad.
\end{abstract}

Palabras-clave: Luiz Ruffato, realismo, modernización, sociedad brasileña, éxodo rural.

Não entendo como você pode escrever tudo isso! - onde não há nada de belo, nem de bom! [...] Para que revelar tudo o que é esquálido, miserável... ninguém consegue ler este livro sem se sentir mais infeliz e ruim.

Carta de Gertrude Tennant a G. Flaubert, sobre Madame Bovary, 1857.

\section{Um inferno particular}

Falar sobre realismo em literatura, passadas já duas décadas do século XXI, parece anacrônico e dispensável, num mundo em que a própria literatura, pelo menos nas concepções críticas quase inabaláveis durante todo o século anterior, levanta questões aparentemente novas. Poderíamos supor que a inextricável relação entre literatura e sociedade, que chegou a estar sob suspeita,

\footnotetext{
* Universidade Federal de São Carlos (UFSCar), São Carlos, SP, Brasil. Đorcid.org/0000-0003-4823-0123. E-mail: tpelleg@ uol.com.br
} 
enfim se rompeu, pois se acredita que as transformações sociais, culturais e tecnológicas, em todos os níveis, superaram a capacidade da escrita de representá-las ou refleti-las, seja qual for o termo preferido. Certezas seculares, posturas comprometidas, conviç̧ões éticas e regimes estéticos, que sustentaram a sempre vã tentativa de "capturar o real", nas artes e na literatura, ou seja, o que se entende por realismo, cheiram hoje à naftalina das gavetas vazias.

No entanto, há autores que, cada qual a seu modo, requerem um olhar mais agudo sobre os recursos narrativos utilizados na elaboração de temas comuns às literaturas ocidentais, aqui em particular a brasileira, reiterando mais uma vez a relação inescapável entre literatura e sociedade. Entre eles está Luiz Ruffato, muito conhecido de público e crítica, notadamente pela exposição na mídia, hoje inescapável, e pelos vários romances publicados, alguns dos quais foram reunidos em único volume, Inferno provisório (2016), um complexo mural fictício que procura construir, segundo o próprio autor, uma história dos trabalhadores brasileiros, na perspectiva deles, algo muito raro até então: "Pode parecer pretensioso, mas eu queria que o conjunto de minha obra fosse épico, no sentido de que fosse a história do proletariado brasileiro" (Ruffato, 2006).

O que tem despertado atenção nesse objetivo ${ }^{1}$, - reafirmado em inumeráveis entrevistas, depoimentos e palestras - é que ele provém da própria vivência do escritor, nascido em Cataguases (MG), filho de família de simples trabalhadores, cuja experiência de vida se espelha na ficção. Ele procura fugir, assim, de um olhar "exótico", aquele de um escritor burguês ou de classe média que se debruça sobre as vicissitudes das classes populares. Com evidente dimensão e função políticas, assentadas na transposição realista de matéria social bem concreta, ele se aproxima subjetivamente da tragédia da modernização brasileira conservadora, baseada na exploração, no abandono e na violência que, quando não matam, aleijam física e mentalmente. Dessa maneira organizou seu inferno particular, metonimicamente, pois cada história de vida ali narrada - como a dele, possivelmente - é apenas uma pequena parte de um todo, que a enforma e constitui. E esse inferno não é provisório, é permanente, na medida em que remete à sempiterna organização social brasileira e suas iniquidades.

Representar a história do proletariado brasileiro, formando-se nas cidades como rescaldo do êxodo rural, uma camada social caracterizada por seu modo de vida cheio de impossibilidades, na qualidade permanente de assalariados, sem perspectivas outras além de viver da mão à boca, é figurar a história da reiteração de um estado de coisas peculiar não só à região de Cataguases, mas a muitas regiões de todo o Brasil, sobretudo durante a ditadura militar (1964-1985). Para essa representação, Ruffato escolheu uma forma literária que, num certo sentido, se contrapõe à forma do discurso hegemônico do progresso para todos, sem contradições, na medida em que estabelece uma espécie de contradiscurso fragmentado, uma recusa deliberada da linearidade e da temporalidade cronológica, criando frestas e fissuras, estilhaçando o antigo modelo de espelho realista. Ali o leitor procura se mover, andando em círculos, espiando, recolhendo cacos, refugos, indícios, em busca de personagens que se perdem na vida e no relato.

\section{Um realismo de hoje}

O realismo de Ruffato é de hoje, digamos assim, e parece repousar, mais do que em qualquer outra, na concepção de que esse regime estético é - principalmente - um esquema de entendimento e modelagem das estruturas e relações sociais, carregando consigo funções e efeitos diversos, de acordo com o recorte temporal e espacial que ele escolheu: desde o início dos anos 1950 até os anos 1990, na região sudeste mineira, envolvendo as cidades de Cataguases, Rodeiro, Leopoldina, Juiz de Fora e outras. Foi nesse período que a região se transformou sensivelmente, passando de um perfil econômico e social agrário e conservador para agente e paciente de um processo de urbanização desenfreada e desarticulada, com

\footnotetext{
${ }^{1}$ Trata-se de um projeto de longo curso, só efetivamente terminado com o volume publicado em 2016, pela editora Companhia das Letras, o qual serviu de base para este trabalho.
} 
consequências dramáticas para a maioria dos habitantes. É esse barro que o autor modela, criando tempos e espaços, temas e situações.

Vale a pena recorrer, pensando nesse aspecto em particular, ao clássico estudo sobre os caipiras de São Paulo, Os parceiros do Rio Bonito, em que Antônio Candido analisa, além das condições de vida objetivas, as representações mentais do homem do campo do estado de São Paulo, quando se viu premido por condições econômicas adversas, semelhantes às mencionadas acima. O sociólogo explica:

Dado o processo de urbanização, que interrelaciona todas as áreas do estado, os problemas econômicos têm agora - e cada vez mais - ressonância nos cantos mais isolados, embora não atingindo a todos igualmente. É portanto compreensível que o caipira manifeste a seu modo sintomas de inquietação e apreensão, gerais em toda a população, embora ocorrentes de modo diverso conforme o lugar, a integração social, o nível cultural e econômico (2010, p. 225).

Publicado originalmente em $1964^{2}$, esse livro analisa as relações entre literatura e sociedade, a partir da poesia popular da região escolhida para pesquisa (o cururu), enfatizando logo no começo que a pesquisa "das condições de vida do homem do campo não deve ser baseada apenas em enunciados políticos, ou em investigações especializadamente econômicas e agronômicas, mas também no estudo da sua cultura e da sua sociabilidade" (Candido, 2010, p. 13).

O livro de Ruffato, nesse sentido, não deixa de ser um estudo sociológico e psicológico, vazado em excelente literatura, sendo que determinados aspectos das categorias narrativas utilizadas lançam boa luz sobre um processo que, além de individual e subjetivo, é social, mais que ficcional, é real. Os herdeiros desafortunados de um êxodo rural concreto, transformados em personagens com sonhos e pesadelos, estão representados na obra, ficcionalizadas as especificidades locais e temporais do processo social que o escritor quis resgatar, não como simples pano-de-fundo, mas como feridas abertas ou cicatrizes latejantes também no corpo do texto. Voltando a Candido, a inquietação e a apreensão que ele capta em seus "parceiros" é muito semelhante às dos personagens ruffatianos e têm como resultado, para todos, uma vaga percepção do fim de uma "era onde tinham razão de ser como tipos humanos" e conclui:

E pode, em certos casos, dar nascimento, como mecanismo de compensação, a verdadeiras miragens econômicas e sociais, causadas pela insatisfação e o desejo de fuga, que os levam a buscar zonas novas, ou a cidade, mesmo sem a premência excepcional das dificuldades correntes (2010, p. 227).

Tais miragens, comuns a quem foge, em qualquer época e lugar, também no campo da ficção de Ruffato são o resultado dos efeitos devastadores da transformação gradativa da terra da região em propriedade privada, o que inviabilizou a fixação dos trabalhadores na lavoura, empurrandoos para as cidades. Ali vendem seu único capital, a força de trabalho, que inclui o corpo e os afetos. Nesse processo, constantemente repetido, privados das antigas condições de sobrevivência na roça, passam a viver de salário, o que lhes imporá limites quase intransponíveis e definirá sua inserção mal costurada no tecido social urbano. Â medida que as cidades crescem, eles diminuem e os traços que os definiram enquanto sujeitos vão sendo alterados e incorporados ao processo que os transforma em mercadorias descartáveis (Oliveira, 2017, p. 164).

Por conseguinte, tomando uma realidade humana sem nobreza, elevada à dignidade da representação, como diria Auerbach (1976), em que pessoas comuns tornam-se personagens ficcionais dotadas da nobreza particular da figuração artística, com diferentes modos de focalização, organizam-se as refrações necessárias para obter um realismo particular e muito produtivo, em uma espécie de simbiose entre o real e sua representação. Trata-se do "processo de democratização" da literatura, aludido por Rancière: "a subversão das hierarquias da representação [...] a adoção de um modo de focalização fragmentada, ou próxima, que impõe a presença bruta em detrimento dos encadeamentos racionais da história" (2014, p. 35).

\footnotetext{
${ }^{2}$ Como afirma Candido (2010), no prefácio, “a própria situação estudada se alterou”, mas "descreve um processo e uma realidade humana, característicos do fenômeno geral de urbanização no estado de São Paulo", que, acrescento, seguiu parâmetros semelhantes em outros estados, inclusive no de Minas Gerais.
} 
Enunciando essas representações em elisões, cortes bruscos e inesperados, lacunas propositais, sobreposições e hiatos - as feridas e cicatrizes do texto -, consegue-se a exata dimensão da força constritora que a realidade exerce em seres que não tiveram e não tem nenhuma possibilidade de escapar, seja no passado, no presente ou no futuro. Desse modo, colocam-se estes diferentes tempos em uma relação vertiginosa, pois se foge da referência histórico-cronológica, à revelia do que o próprio autor delimitou, a saber, as três últimas décadas do século passado. Ou seja, trata-se da captura de temporalidades e espacialidades múltiplas, individuais e coletivas, assentadas em experiências sensoriais das próprias personagens.

Não se trata de um simples processo de registro fictício da história da região e das pessoas, nem das minúcias concretas que compõem o real de cada sujeito - embora ali estejam em profusão -, mas a elaboração de um tipo de figuração literária que engloba a utilização do realismo clássico, bastante descritivo, com sua utópica objetividade documental e impassível, acrescida de seu oposto, as já antigas liberdades modernistas, subjetivas e aleatórias. Tem-se assim um amálgama ao qual se poderia aplicar o conceito de "realismo refratado" (Pellegrini, 2018, p. 17), uma espécie de decomposição de formas e cores, muito clara na estruturação das categorias narrativas e no tratamento dos meios expressivos. Procurando destruir a ideia de uma totalidade, mesmo assim os textos dessa enorme composição - impossível de analisar em detalhes neste espaço - traduzem as condições específicas do universo que pretendem representar: apodrecimento, desterro, exílio e sofrimento irremediável.

Se a já antiga fragmentação modernista se torna, então, o recurso estilístico essencial da construção do realismo da obra, percebe-se que este também se vincula ao uso de uma oralidade típica da região. Nesta está embutida uma identidade cultural própria, historicamente delineada, expressa na organização sintática e na acumulação vocabular coloquial, maturados na herança italiana, portuguesa e cabocla. Em arrancos, solavancos, curtos-circuitos e lapsos, evidenciados por uma pontuação peculiar, a linguagem se derrama, revelando, geralmente com o recurso da memória das personagens, a precariedade dos laços sociais, sendo a realidade percebida como categoria absolutamente negativa no interior do processo narrado. Desnudam-se, assim, o conflito e o drama como propulsores das relações humanas, tanto entre as personagens, quanto entre elas e seu universo, enfatizando a injustiça social e a incompletude do ser.

Tal como Zito Pereira, no capítulo "A danação", preso em uma cela, rememorando sua vida e procurando entender porque agora está ali:

Bebi demais. Amanhã, vou contar pra Hilda, ela vai morrer de rir. Preso? Ah, Zito, lá vem você com histórias... ia acordar, tomar mingau de fubá com ovo, bebericar um café, pegar a bicicleta, Culpa minha, fiz besteira, me arrependo até hoje, nunca mais tive sossego, Tentativa de homicídio, engaiola o crioulo, Doutor, vou dar umas bordoadas nele pra ver se ele para de choramingar, que homem mais mole, sô!, Hilda?, o quê que aconteceu? [...] por quê?, sei lá, bobiça, a gente comete umas besteiras na vida, depois fica pensando, não entende porque fez aquilo, você vai me esquecer (Ruffato, 2016, p. 70).

Além disso, existe uma desestruturação proposital da forma romance - ela mesma uma refração -, sempre muito mencionada pelo autor e pela crítica. Sendo composto pela junção de romances anteriores ${ }^{3}$, Inferno provisório, como eles, é organizado em capítulos autônomos, cada um deles uma história fechada, um conto, que mantêm uma forte ligação entre si, com o reaparecimento aleatório dos mesmos personagens e a volta cíclica aos mesmos lugares, por meio da memória ou não, o que sempre evidencia novos pontos de vista. Assim, têm-se relatos que podem ser lidos em qualquer ordem, sem conexão temporal aparente, como índice geral da própria fragmentação do gênero romance, forma ainda hoje definida como a grande epopeia burguesa, consolidada no século XIX e que mais uma vez não teria razão de ser. Mas tem, pois o realismo aqui é estratagema para mantê-la viva, não como epopeia, mas como tragédia ou

\footnotetext{
${ }^{3}$ Mamma son tanto felice (2005), O mundo inimigo (2005), Vista parcial da noite (2006), O livro das impossibilidades (2008) e Domingos sem Deus (2011). O autor, dez anos antes, explica que há grandes mudanças na elaboração do volume único: "O que eu fiz foi pegar esses dois livros e reescrevê-los em Inferno provisório [...]. Tanto que as histórias do segundo livro mais ou menos conformam a do primeiro [...] e eu ainda tenho uma história [...] que só vai aparecer no quarto volume de Inferno provisório" (Ruffato, 2006).
} 
elegia dos conteúdos humanos ordinários e degradados, rejeitos do desenvolvimento do capitalismo ao longo do último século, notadamente nas periferias do globo.

A adequação do seu grande mural a este ou àquele gênero era preocupação do autor desde seu primeiro sucesso, Eles eram muitos cavalos (2001): “Como posso escrever sobre a classe média baixa, sobre o proletariado, usando uma forma, o gênero romance, que foi criado para dar uma visão de mundo da burguesia?" (Ruffato, 2006). A forma encontrada foi a insistência nos capítulos estanques do travejamento narrativo, significando a precariedade das relações interpessoais e sociais, e, nos recursos expressivos, os lapsos de linguagem evidenciando a incomunicabilidade entre as pessoas desse contexto desossado e brutal.

Desse modo se revela o realismo refratado de Ruffato: por meio do que Adorno (2003) chamou de "antagonismos formais", ou seja, da incorporação de um impasse à própria forma, ele elabora um tecido denso e fechado, circular, apoiado em uma postura ética e política, que a temática confirma. E por meio de um método quase documental, mescla soluções modernas e contemporâneas com outras do realismo clássico, tais como o narrar e o descrever, impossíveis de evitar em qualquer relato. Assim se entrecruzam todo o tempo diferentes pontos de vista, elaborando as tragédias mínimas que enfatizam mágoas e angústias de homens e mulheres, sujeitos despossuídos, abandonados à própria sorte. Como o professor de $O$ segredo que, educado em seminário para escapar da fome, e, sem esperanças, chega a engendrar a própria morte:

Compreendi então que encontravam-se desfeitos os laços de família. [...] Estudava para padre, ia ser alguém na vida... Mal sabiam eles que engendrava minha perdição. Porque quanto mais conhecia, mais queria conhecer; e quanto mais conhecia, mais infeliz me tornava... Sou um homem só... Um homem só no mundo... Perdi minhas antigas referências, a roça, meu sangue, a paisagem da infância... E não acrescentei nada a isso... (Ruffato, 2016, p. 134).

\section{Tragédias mínimas}

O primeiro relato do romance se intitula "Fábula" e isso já leva o leitor a pensar que vai enveredar por uma daquelas histórias fantasiosas, de cunho moral implícito ou explícito, nas quais as personagens são animais com características humanas. Na verdade, em uma inversão proposital, o escritor aí apresenta seres humanos quase em estado de natureza, que extravasam consciente ou inconscientemente instintos ligados apenas às necessidades mais primárias de sobrevivência, seres inferiores à sua própria humanidade. São os primeiros habitantes daquelas brenhas, instalando-se nos arredores do núcleo de Cataguazes, já existente, em Rodeiro e outras pequenas localidades. Imigrantes italianos (Michelettos, Bettios, Spinellis, Finetto, Benevenuttis...), supostos ancestrais do próprio autor, labutam em meio à terra inóspita da Zona da Mata mineira, que lhes caberá desbravar com ferocidade, muitos ódios, rancores e nenhum remorso. Como a insinuar que, desse passado brutal, nada do que vier poderá ser menos terrível, mesmo modificando-se aos poucos as condições do viver e sobreviver. Foi o Micheletto velho quem sozinho fez a limpa daquela grota, daquele "mataréu vassalo de bestas selvagens", que secou de tantos partos a mulher em vida, matou a própria filha e sujeitou os filhos homens, sobrados dos quantos nasceram.

Depois que enterraram a Louca, o Pai, besteiro, concordando na diáspora dos sobrantes, dispersos aos quatro cantos, sitiou-se na fazendola, homiziado entre os animais, comendo, bebendo e dormindo com eles, bicho ele mesmo, [...] depois alusão, lenda, nada, enfim: a barroca asselvajada, temida, submersa no silêncio primevo, encapsulada no esquecimento, suspensa na memória (Ruffato, 2016, p. 18).

O que poderia advir desse passado? $\mathrm{O}$ autor e seus narradores respondem aos poucos, em cada relato, construindo o mural deteriorado de uma história de fracassos e sonhos desfeitos, carregando o peso do inferno inicial, em indisfarçado determinismo.

A pequena colônia italiana inicial de Rodeiro, de onde veio Ruffato, estabeleceu-se com os primeiros imigrantes, vindos do litoral paulista e de outras pequenas cidades de São Paulo e Minas, procurando simples possibilidades de vida e, depois, de enriquecimento. "Era uma porcariinha 
assim Rodeiro, uma praça, quatro ruas" (Ruffato, 2016, p. 311). Estabeleceram-se como posseiros de terras devolutas, povoadores isolados, sem passado e sem história, que deixaram para trás. Do cultivo de subsistência passaram mais tarde à produção de café, sendo que as terras por eles cultivadas sofreram, mais tarde, com a decadência econômica da região, sobretudo com o declínio da cultura cafeeira praticamente em toda a Zona da Mata (Oliveira, 2017, p. 153).

É a partir desse substrato que o escritor tenta apreender o início do êxodo dos viventes dessa pequena comunidade rural, na região onde o Michelleto velho, faminto e arruinado, cumpriu sua existência. É o momento em que os filhos dos imigrantes começam a migrar também, para Cataguases e outras localidades, onde se formava uma indústria de tecidos e outros itens, oferecendo mais oportunidades que a lavoura já arcaica. Mais tarde, seus filhos, buscando as grandes cidades, perseguem os sonhos gestados pelas promessas de milagres da ditadura militar.

Dealtry afirma que a cronologia do romance é a consolidação de um sistema de exclusão de parte da população, "o lavrador que retira da terra sua subsistência, passando pela formação maciça do operariado, até a dispersão dos núcleos familiares em direção às periferias das capitais" (Dealtry, 2009, p. 212). Na verdade, em termos sociais, não há excluídos, mas sim incluídos em condições econômicas, políticas e sociais degradantes; não se trata um fenômeno novo originado a partir de disfunções sociais, mas algo inerente às sociedades capitalistas, que precisam de trabalhadores inclusos e indispensáveis no injusto e desigual enredo dos modos de produção no Brasil. A exclusão está associada a uma espécie de inutilidade econômica e morte social, a ausência de um lugar reconhecido na sociedade, já a inclusão determina um lugar solidamente estabelecido na base da pirâmide (Vettorassi, 2018, p. 61).

Tanto na realidade quanto na ficção ruffatiana, trata-se de um processo perverso, no qual existem somente duas opções objetivas: o êxodo, como revolta possível, ou a aceitação passiva da inviabilidade da vida no lugar. Isso só se aprofunda, sendo que a percepção da exploração instiga a esperança de vida melhor em outras paragens, onde mais uma vez as personagens fracassam e se perdem. Acresça-se a isso o fato de que se cria, em ambas as situações, uma espécie de "cultura da solidão", uma subcultura de isolamento social, baseada em um sentimento psicossocial de pertencimento a lugar nenhum. Acentua-se a perda dos costumes, das crenças, da língua e da própria identidade. O presente de frustrações ou a memória de um passado idealizado acendem, então, o desejo de ir para mais longe ou de retornar à casa da infância, "paraísos perdidos" que nunca mais serão reencontrados.

Rodeiro, Ubá, Cataguases, São Paulo ou Rio de Janeiro? Partir ou ficar? Não há possibilidade segura. É o complexo embaralhamento das narrativas que deixa perceber, aos poucos e de forma incerta, "o modo de se organizarem e se determinarem os alvos de ascensão e como estes se abrem ou se fecham à sua realização" (Oliveira, 2017, p. 158).

Como Vanim, em "A decisão", cujo sonho era ser cantor famoso, e é um dos que escolheu fugir, mesmo casado com Zazá, operária da tecelagem. Depois do casamento, premido pelo peso de um quotidiano mesquinho, pendurou seu violão na parede do quarto e resolveu de fato trabalhar. Mas um dia "sentiu um troço esquisito, uma gastura", tirou o instrumento da parede e embarcou num ônibus para o Rio de Janeiro, em busca de um utópico sucesso no mundo do rádio.

O ônibus encostou, a porta abriu, Vanim percorreu afoito o corredor, observando a fisionomia de cada um, ninguém conhecido, Graças a Deus! Sentou, o motor roncou, $\hat{E}$, meu povo vou embora, adeus!, as luzes apagaram, atravessou a ponte Nova, cortou a Vila Minalda, Meu Deus, o quê que estou fazendo?, pegou a estrada rumo a Leopoldina, Cataguases, sumiu atrás dos morros, o breu da noite, vontade de levantar, falar para o motorista que tinha esquecido os documentos em casa, [...] seu corpo não se mexeu no entanto, Meu Deus, a Zazá vai querer me matar... (Ruffato, 2016, p. 46).

Como tantas outras personagens, Vanim desapareceu nas páginas de Inferno provisório, onde não há protagonistas. Lavradores, operários, desempregados, pequenos comerciantes, biscateiros, velhos, moços, mulheres e muitas crianças são personagens a percorrer um caminho de fracassos externos e internos, enredados numa teia apertada que não conseguem romper, num quotidiano marcado dia a dia, hora a hora, pela impossibilidade. São feios, sujos e 
desprotegidos - como os personagens realistas e naturalistas dos oitocentos -, mas aqui são figuração dos restos humanos dos grandes projetos frustrados da modernização brasileira conservadora, consolidada no regime militar, a um preço alto demais. Rescaldos da história dos últimos cinquenta anos: o progresso juscelinista, a ditadura militar e seu milagre econômico, os projetos de integração no circuito do capitalismo global, o consumo como índice de prosperidade. O automóvel, a televisão, o rock, o futebol...

Gerson arremata um petardo, a bola aloja-se no canto esquerdo de Albertosi Gooooooooooooooooooooool! Brasil dois a um! Eu te amo meu Brasil, eu te amo / meu coração é verde, amarelo, branco, azul anil [...] Brasill1111111! (Ruffato, 2016, p. 350).

Todas essas etapas estão representadas inclusive em uma miríade de pequenos ícones materiais reais de cada época, que vão de marcas de carros e bicicletas a eletrodomésticos, itens de higiene pessoal, alimentos, bebidas, medicamentos, peças de roupa, sapatos, letras de canções populares, gestos, atitudes e expressões orais, uma profusão caleidoscópica de sinais que o leitor reconhece (ou não), acentuando-se a verossimilhança por meio de uma espécie de pacto afetivo entre ele e os diferentes narradores. O olhar dos narradores está sempre atento ao minúsculo, ao ínfimo, ao aparentemente insignificante, que, no entanto, não é formador de um mero "efeito de real", mas significante criador de outros sentidos, auxiliar da interpretação dos processos sociais gestando vidas sempre fanadas. Como Seu Miguel, que amontoa itens e dívidas, por ter sido enganado nos negócios de secos-e-molhados com os quais sustentava oito filhos, em "Cicatrizes":

A carroça, pagou-a à vista [...] sacas de arroz em casca e limpo, feijão, fubá, açúcar, farelo, farinha de trigo; rolo de arame farpado, bacia de alumínio, balde; bobina de papel; fardos de vassoura, corda, fumo, macarrão; lampião, lamparina; óleo, querosene; e enfurnados em sacos de estopa, leitões, frangos, patos, gatos [...] (Ruffato, 2016, p. 141).

Ultrapassam-se o simples descritivismo e mesmo um possível determinismo de molde naturalista, pois se movimentando nesses espaços tão fechados e atulhados na sua escassez, as personagens veem-se confrontadas com sua própria impotência, sendo que a consciência disso os atormenta e fratura. Assim as tragédias mínimas (Pellegrini, 2018, p. 254) de homens e mulheres descartáveis vão se tornando familiares para o leitor, que as acompanha em cada etapa da história.

Outro acesso de tosse. A mulher recolhia a roupa do varal apalpando as mudas estendidas, encostando-as à pele do rosto para sentir a umidade e, se arranhavam, dobrava-as e jogava-as junto com os pregadores de madeira na tina de plástico verde-escuro que empurrava ao longo do quintal com a ponta do chinelo de dedo de solas gastas. [...] Roupa? Lavara muitas. [...] Calças ricas: tropical, linho, gabardine, tricoline, tergal... Mas também vestidos tristes das mulheres da Ilha: paetês, vidrilhos, lese [...] Quanto tecido suas mãos enrugadas enxaguaram, branco e de cor, de ver Deus e de ficar em casa, de baixo e de sair... (Ruffato, 2016, p. 306).

\section{Para sempre cortiço}

A primeira leitura de Inferno provisório remete de imediato a $O$ cortiço, de Aluísio de Azevedo, como muito já se assinalou. Não há como não reconhecer no Beco do Zé Pinto, onde se aboletam casinhas e prolifera incessantemente o número de moradores, até decair completamente, o cortiço criado por João Romão, que, segundo Ruffato, "consegue [...] falar de um Brasil que ainda ia ser" (Ruffato, 2006). De fato, reconhecendo que há poucas obras brasileiras sobre a classe média trabalhadora, ele declara que se inspirou naquela que seria, salvo engano, o primeiro retrato coletivo mais crítico da exploração econômica e social no Brasil. Mas é bom lembrar que o naturalismo de Azevedo, na verdade o realismo à moda de Zola (Pellegrini, 2018, p. 130), nunca foi aceito pelos intelectuais e pela crítica de seu tempo como uma prática e um estilo literários, sobretudo porque as principais formações sociais que representava e as hierarquias de classe que propunha não eram exatamente as desejadas pela concepção unificadora de uma nação brasileira civilizada à europeia que então se pretendia 
formar. E provavelmente residem também nesse ponto as resistências que, a partir do Modernismo, atravessando todo o século XX, até hoje lhe são feitas.

A questão da nacionalidade, ou sua ideologia, acompanha nossa literatura desde sempre sendo negada ou reafirmada, conforme o período - como uma forma de superar os traumas da colonização, um lugar de discussão sobre os projetos de realização de um país com especificidades próprias. O realismo e o naturalismo entraram pela porta dos fundos dessas concepções hegemônicas, instalando-se nos quartinhos, nas cozinhas, nas alcovas e nos quintais, enquanto, no salão principal, dançava-se. Até hoje os moradores desses espaços incluídos - mas excludentes - incomodam, sobretudo quando, vez ou outra, espiam pelas portas mal fechadas, pelas frinchas, e ousam falar, sentir, viver. É como se a "comunidade imaginada" (Anderson, 2008) do Brasil aos poucos se desfizesse - e se recompusesse - e sua parte rejeitada fosse adentrando o salão. Isso fizeram Aluísio de Azevedo e Luiz Ruffato - e outros, no longo caminho entre eles - cada qual com as condições de possibilidade e premências de seu momento histórico.

É nesse sentido que não há em Inferno provisório uma problemática ligada apenas à "prevalência do eixo espacial" (Dealtry, 2009, p. 211), mas à interrelação de dois eixos, o espacial e o temporal, na medida em que aquilo que hoje é - o "cortiço" de Ruffato - assim é porque historicamente assim surgiu - o cortiço de Azevedo - e se perpetuou, à custa e à revelia de seus habitantes. Em vista desse velho tema, a contemporaneidade de Ruffato reside justamente no modo como ele opera seu realismo, como categoria histórica e social, amalgamada e refratada por experiências e vivências individuais, só possíveis naquele espaço constrangedor, construído ficcionalmente.

A comparação entre os dois romances 4 ampara-se sobretudo na elaboração de duas personagens específicas, cujo caminho segue direções diferentes e opostas. Trata-se de Zé Pinto e João Romão. O primeiro é o dono dos casebres onde mora a maioria dos trabalhadores, tal qual fora João Romão, no século XIX. Trata-se de um arrivista urbano, predador da miséria, mas seu poder tem o limite exato do beco que construiu e explora. Além dele, nada pode, é apenas mais uma roldana de um mecanismo muito maior. A semelhança entre ambos é clara, não só porque são os proprietários de casinhas e quartos alugados, mas porque essa posse representa a acumulação do capital, no Brasil, a partir de sua fase mais modesta e primária (Candido, 1995) com João Romão, até a fase mais selvagem, com Zé Pinto. Em ambos a usura, a falcatrua e o roubo. Mas enquanto João Romão ascende e se aboleta em degrau social superior, Zé Pinto soçobra e é tragado pelo próprio mecanismo de exploração que ajudou a alimentar, pois não existe mais nenhuma condição de escalar até o topo da pirâmide.

Ambientado na década de 1870, O cortiço tematiza a possibilidade de ascensão social para qualquer um que tivesse "delírio de enriquecer" (Azevedo, 1999, p. 19), como João Romão, abusando da especulação e exploração do trabalho, num tempo em que a base econômica brasileira era ainda agrária, mas crescia o proletariado urbano, indispensável para os serviços essenciais no Rio de Janeiro em expansão econômica e demográfica. Já em Inferno provisório, um século depois, a mão-de-obra é excedente nos grandes centros industrializados da região sudeste, devido ao êxodo causado pelo esgotamento das terras cultiváveis na Zona da Mata. O campo se despovoa, "ninguém mais quer ficar na roça, a moda agora é a cidade" (Ruffato, 2016, p. 122), incham as periferias e a ilusão do progresso transforma-se em fumaça, para a maioria. A derrocada crescente se evidencia no passar do tempo. Como o professor, já citado, e sua história de abandono, sonhos desfeitos e remorsos, resultado do passado rural enevoado, que procura decifrar quando um dia volta aos lugares da infância, em busca angustiada:

Lonjuras, tudo vazio, cresce a capoeira, o matagal engole as glebas, sufoca as árvores, carro de boi sem roda apodrece debaixo da cumeeira do que um dia foi rancho de curar fumo, vozes, o vento aboia um lamento, e a palma dos pés como que lê antigas pegadas, vence a noite assoberbada [...] O quê que eu vim fazer aqui, meu deus? (Ruffato, 2016, p. 122-123).

\footnotetext{
${ }^{4}$ Alguns argumentos deste texto foram inspirados na comparação entre $O$ cortiço, de Aluísio de Azevedo e L'assomoir, de Emile Zola, no clássico ensaio "De cortiço a cortiço" de Antonio Candido (1995).
} 
Pode-se dizer que uma figura como Zé Pinto é típica desse período, as últimas três décadas do século $\mathrm{XX}$, durante as quais o Brasil aceitou que os centros urbanos se deteriorassem, em nome da uma modernização para poucos, crescendo cada vez mais cortiços e favelas, sem acolher com o mínimo de dignidade os que deixavam as zonas rurais decaídas, as lavouras devastadas e as terras esgotadas. Essa ruína se alastrou para as próprias cidades, que incharam com o rescaldo vivo do campo, tornado solo fértil para aproveitadores da desgraça alheia.

Em 1890, Azevedo escreveu que "o cortiço aristocratizava-se", "os preços dos cômodos subiam" e "ali já se não admitiam sambas e chinfrinadas" (1999, p. 176), narrando a escalada sórdida de João Romão, enquanto enriquecia. Já sobre o Beco do Zé Pinto, Ruffato conta que cai agora aos pedaços, tornou-se "um pântano de bosta", com "paredes desabadas, telhados caídos", onde "meninos e meninas tímidos, catarro escorrendo dos narizes feridos, frangalhos de roupas" atestam-lhe a decadência (2016, p. 314).

João Romão termina vitorioso, circulando na Rua do Ouvidor, de casaca, recebendo hipocritamente o diploma de uma sociedade abolicionista, depois de ter entregado a escrava Bertoleza ao antigo dono. Zé Pinto, ao contrário, afunda no seu beco até o último degrau, sem ninguém, porque não há mais possibilidades ali além do apodrecimento. Ainda a meio caminho da derrocada física e financeira, já envelhecido, ele rememora as décadas vividas, quando seu nome, construído com práticas violentas e autoritárias, era modelo de progresso e símbolo de poder:

Quem ainda lembra do Zé Pinto? O primeiro na rua a ter geladeira, quando ninguém nem sonhava com isso. A ter televisão, uma coisa tão importante que a janela ficava suja do povo espiando. A ter telefone, que até serviu para ganhar um dinheirinho extra, cobrando pelos recados que recebia e enviava. A ter fogão a gás, enceradeira, vespa, um luxo! Mas para conquistar esses confortos todos, haja tino e tutano! (Ruffato, 2016, p. 265).

O escoar irremediável do tempo vai mudando as coisas para quem sempre manteve a ordem no beco com o poder de seu revólver calibre 38, intimidando e sujeitando os inquilinos aos seus preços e vontades, evidenciando o lado mais instintivo das personagens, brutalizadas por aquele meio: "Antes, era falar Zé Pinto que a gente honesta e trabalhadora e os malandros e vagabundos batiam o queixo. Porque com ele era assim: pão-pão, queijo-queijo" (Ruffato, 2016, p. 265). Até que um dia, anos depois, Josemar, antigo morador do beco, roído pelas lembranças, também volta a Cataguases, em busca do seu tempo perdido e, "sem se dar conta achou-se na entrada do Beco do Zé Pinto, o visgo do passado impregnado em sua roupa":

No quarto escuro, abafado, fedendo a mijo recente e azedo de restos de comida, imbecilmente sentado numa cadeira de rodas, abandonado a um canto, móvel sem utilidade, um cobertor imundo a cobrir o graveto das pernas, Zé Pinto, baba no canto da boca, o corpo penso, inerte [...] onde a cara que amedrontava os inquilinos, que chispava fogo sobre quem fosse, os embrulhões, a polícia, os cobradores, os parentes, os ladrões, os espertos, as autoridades? [...] (Ruffato, 2016, p. 314).

A derrocada, o fracasso, a invalidez, o esquecimento. Pode-se especular que a comparação do cortiço com o beco - a passagem de um ao outro - tem um quê de alegoria, na medida em que pode representar a débâcle do desenvolvimento brasileiro, em que a acumulação de capital, por meio da exploração feroz, mais de um século depois, deixou no seu rastro, para a maioria, não mais o sonho da ascensão, mas o pesadelo do fracasso.

\section{Sem remédio}

O conjunto de Inferno provisório permite entrever a crença, muitas vezes reiterada pelo autor, da necessidade de o escritor intervir na organização da sociedade, por meio de uma postura empenhada, apontando com método os aspectos negativos da modernização brasileira das últimas décadas. Não se vislumbra a possibilidade de que possa haver superação dos limites 
impostos pelo contexto que apodrece ${ }^{5}$ as personagens, tanto as que ficam como as que tentam fugir; existe uma visão absolutamente negativa do processo que influiu no destino de grupos inteiros, dos que só tomaram parte nele como refugos, permanecendo sempre à margem ou sofreram drasticamente seus reveses.

É o que se vê, por exemplo, em "Amigos". Na véspera de Natal, Luzimar reencontra Gildo, agora o dono orgulhoso de um Fusca 1300 verde, com placa de São Paulo, que volta para visitar a mãe. O diálogo que se segue, em avanços e recuos, tateios e titubeios marcados na pontuação, escancara o desencontro e a mesma mágoa, tanto de quem partiu como de quem ficou. Luzimar se retrai, acuado pelo aparente sucesso do outro, que ataca com o ressentimento à flor da pele de quem sequer pode voltar, pois não encontra mais as próprias raízes. Em carne viva, o exílio da própria memória.

Eu tenho pena de você, cara. Pena mesmo, juro... Porque você está fodido...já estou vendo: daqui a pouco vêm os filhos, uma fieira deles, e você aí, dando duro na fábrica. O salário não chega, eles param de estudar, vão pegar no batente para ajudar... E você ficando velho... Um dia, quando menos perceber, acabou... é o fim da linha... E que merda de vida você levou, cara!, que merda de vida! [...] Eu me dei bem, entende? Todo mundo que foi embora se deu bem... Agora, o pessoal que ficou aqui... estão todos fodidos...Todos! que nem você: fodidos! (Ruffato, 2016, p. 248).

Pouco se descreve neste "conto" em particular e em alguns outros, como se faria no realismo clássico. O principal se inscreve nos diálogos, nos cacoetes da fala, entrando abruptamente no texto, "como se apropriados e incluídos na sua própria materialidade" (Schøllhammer, 2016, p. 242). Uma presença bruta que acentua a verossimilhança e, no caso, a dolorida pungência do fracasso inevitável. Pode-se supor que o embate entre o "de dentro" e o "de fora" residiria na comparação entre quem prosperou lá longe e quem estagnou ou afundou no lugar. Na verdade, trata-se da representação de que não é dado a ninguém ser "parceiro" da própria história, naqueles tempos e espaços, pois estes são moldados por fatores estranhos à própria vontade dos indivíduos. Gildo parece ser o mais afetado, pois mesmo sendo "de dentro", ultrapassou uma fronteira; sua posição é ambivalente, tornou-se estranho no território que foi seu, pois este não existe mais, senão nos seus desejos de retorno, talvez inconscientes, que o diálogo insinua: "Eu reconheço as casas, o calçamento, as árvores, tudo é mais ou menos igual... Mas é como se fosse outro mundo... As pessoas são outras, Luzimar, e a cidade é deles, não é mais minha, entende?" (Ruffato, 2016, p. 248). A posição de Gilmar é menos dolorosa, pois parece ter-se conformado com seu horizonte cheio de limitações e muito além de seus sonhos: "Ê, Gildo, quem é você para falar assim comigo?" (Ruffato, 2016, p. 248).

Não há para os homens e mulheres ruffatianos nenhum horizonte utópico; estão esmagados pelas circunstâncias, responsáveis por aniquilar qualquer caminho diverso daquele que o destino parece impor. Mas não há nada de imponderável nesse destino, traçado pelas condições econômicas e pela organização dos estratos de poder, os quais, direta ou indiretamente, impõem suas regras visíveis e invisíveis. O trabalho é uma dessas instâncias: ter ou não ter um trabalho formal é o que diferencia o pobre do muito pobre, sendo que a maior parte dos empregos advém da família mais poderosa da região, os Prata: "cheiro bom de povo rico, acabado de sair do banho" (Ruffato, 2016, p.321). Trabalhar ou não para eles, os donos das fábricas, define os sentidos do mundo e os sentimentos de orgulho ou vergonha. Os Prata, mesmo sem materialização corpórea, são espectros presentes em tudo, lembrados a qualquer instante como símbolo de poder estabelecido (Oliveira, 2017, p. 148). Como em "Roupas no varal": "Pelo menos um filho meu não vai trabalhar pros Prata!", “Ô, Raul, não cospe no prato que você come, não... A nossa família..." e "Exploradores!, o que eles são" (Ruffato, 2016, p. 161).

Nesse cortiço ficcional, o autor desenvolveu alguns temas que, se não são originais em relação aos do realismo clássico brasileiro, adquirem uma roupagem contemporânea devido à

\footnotetext{
${ }^{5}$ A epígrafe da obra é exemplar nesse sentido. Trata-se de um poema de Jorge de Lima, de que cito um fragmento: "Também há as naus que não chegam / mesmo sem ter naufragado: / [...] mas simplesmente porque / já estavam podres no tronco / da árvore de que as tiraram.”
} 
intensidade com que são desenvolvidos, o que não se relaciona à crueza "visual" objetiva, mas à pungência, pois são filtrados pela subjetividade das personagens. Um desses temas é a violência, inscrita nas próprias relações sociais, como legitimadora, no plano narrativo, da impotência e da degradação, sequelas da modernização conservadora, no plano real. A promiscuidade e a miséria crescentes resultam da coexistência íntima dos explorados com o explorador interposto, Zé Pinto, enquanto os verdadeiros donos, "os Prata", pairam acima de tudo, raramente aparecendo. A convivência desses opostos é logicamente possível pela própria natureza do processo aí alegoricamente figurado, sendo que este parece o mesmo que o movimento da narrativa, pois existe um sistema de relações concretas entre as personagens, os tempos e os territórios em que se movem, os quais, aos poucos, vão se desvanecendo e apagando.

No ambiente infernal das quatro décadas retratadas, tanto em sentido material quanto psicológico, as personagens mais exploradas e violentadas são mulheres e crianças; muitas destas crescem e mais tarde conseguem sair, a maioria daquelas afunda ali mesmo. De qualquer modo, sair ou ficar são elementos da mesma equação, cuja resolução é zero. Não por acaso, logo no início, em "A mancha", tem-se a morte seca de um menino, filho de uma lavadeira, atropelado por um caminhão, como uma espécie de sinal:

Bibica batia roupa debruçada no tanque, quando ouviu a freada brusca. O pelo de seus braços arrepiou, enxugou as mãos no avental, por instantes paralisada, fora de si. Naquela noite tinha tido um sonho ruim [...]. Ao chegar ao passeio, Zulmira a abraçou, em prantos, Que desgraça, Bibica, que desgraça! [...] E ali, à sua frente, o resultado de todo o seu sofrimento: o caixãozinho roxo da Prefeitura deixa à mostra o corpo magro de Marquinho, a cabeça envolta em gaze. Um desastre tão estupido, meu deus, tão estupido! (Ruffato, 2016, p. 26).

Já se tem aí a reafirmação da tradição da violência da sociedade brasileira, que vitima mais mulheres e crianças pobres e miseráveis, sobretudo se forem negras ou pardas. E o corpo das mulheres, sempiterna moeda de troca, incorpora a violência ancestral da prostituição, de que poucas conseguem escapar no universo ruffatiano. Como Bibica, personagem do excerto anterior, que já era "uma mulher desiludida, quando largou a Ilha" (Ruffato, 2016, p. 26), a zona do meretrício de Cataguazes, para ser lavadeira, profissão comum nos becos e cortiços. Ela sofre com essa "mancha" na sua vida; por causa dela, cede a Seu Antônio Português, de quem, em troca de mantimentos, gera um filho, Marquinhos, cuja morte deixa no asfalto uma mancha indelével de sangue. Na trajetória da maioria das mulheres da obra estão presentes a decadência e a humilhação. Elas são usadas e abusadas na Ilha ou envelhecem esperando os maridos esgotados, dobradas nos tanques, debruçadas nos teares das fábricas ou nas máquinas de costura: "moldes, chuleios, pespontos, cerzidos, alinhavos, arremates, caseado, pregas, mangas, cavalos, colarinhos, barras, decotes, golas, abotoamentos, bolsos, punhos" (Ruffato, 2016, p. 329).

Tal como em "Sorte teve a Sandra", em que a menina de dezesseis anos é levada ao Rio de Janeiro pelos Prata, para trabalhar como empregada doméstica, "no ramerrão encarcerada, arrumar, limpar, cozinhar, lavar, passar" (Ruffato, 2016, p. 322). Ela percorre o caminho conhecido, amante dos homens da casa, namorados na rua, dois filhos abandonados; depois, "soube-se com Aids" [...] Alardeavam, o bairro inteiro, que ela sim, tivera sorte, porque, ao invés de encafuar em Cataguazes [...] correra mundo, tornara esperta, astuta, ladina e agora podia desfilar pelas ruas da cidade" (Ruffato, 2016, p. 324).

Os filhos dessas mulheres andam rotos, sujos e famintos, fazendo bicos nas vendas e calçadas, roubando frutas nos quintais, experimentando sexo nas moitas, nos becos escuros, nos quartos atulhados da miséria. Sua escola é a tala de couro, a vara, o correião, como em "Estação das águas": "Então, passou a espancá-lo, e com tal violência que, apiedados, os vizinhos suplicaram, Chega, Zé, chega, que você mata esse menino" (Ruffato, 2016, p. 95). O autoritarismo e a violência paterna ou conjugal subjugam esposas e filhos, vitimando-os com cenas recorrentes de todo tipo de agressão. Tais arroubos de violência estão ligados às concepções cristalizadas de masculinidade e macheza, que acompanham as personagens desde o início, nas comunidades rurais até a periferia dos centros urbanos. É a estrutura de um mundo particular e arcaico não completamente eliminado por uma modernidade ambígua alardeada desde os "cinquenta anos em cinco" e não implementada para a maioria. 
Todos os fins, todas as utilidades corpóreas e/ou psíquicas, são sempre apropriados por um poder mais forte, que lhes imprime uma função desumanizadora. Nesse sentido, o preconceito racial também se desvela, mostrando a fluida marcação dos lugares sociais na estrutura formada no mundo ficcional e na matéria de que se nutre: "Deve ser porque sou preto, preto é o cachorro do mundo" (Ruffato, 2016, p. 67). Em "A expiação", uma narrativa de complexa sequência temporal, o negro Badeco, criado pelo italiano Orlando Spinelli, depois de ser humilhado várias vezes pelo pai-patrão, na praça, mata-o num momento de descontrole.

Orlando agarrou-o, "Para padrim, para", deu-lhe uma gravata [...] Badeco resistiu, mas o Orlando pegou o relho e acertou-lhe duas chibatadas nas costas. "Ai, padrim! Ai, padrim!" E começou a desfilar. Orlando cortava a couro o ar. E agrupou um povo: uns, os mais velhos, protestavam que aquilo era um absurdo, Aonde já se viu uma coisa dessas?!; outros, os mais novos, lançavam gritos de incentivo, Vai, Badeco, ôôô! Na terceis volta, Uh! Badequim!, Uh! Badequim, surgiu um soldado, 'Para com isso, já!" Orlando mirou-o e falou, dirigindo-se à aglomeração, “Ué, um macaco veio salvar o outro?! E a horda caiu na gargalhada (Ruffato, 2016, p. 208).

A organização formal da matéria violenta oferecida pela realidade atinge a crueldade. Violência é sinônimo de brutalidade, implicando força, ímpeto, intensidade; já a crueldade requer sutileza, argúcia na escolha dos métodos e cálculo na elaboração. Orlando Spinelli utiliza ambas, porque isso lhe é permitido: "O Badequim não liga, ele sabe que é brincadeira" (Ruffato, 2016, p. 208). A cor da pele determina a ordem do mundo, mesmo que não haja mais escravos.

De modo geral, o desconsolo é o elemento fundante de toda a obra. A decepção e o consequente desconsolo como fatos acabados, sem mais perspectivas, organizam os recursos de intensidade e tensão presentes em cada história, que vão lentamente desenhando para o leitor um conjunto (des)organizado, de modo a mantê-lo enredado no imenso desenredo, esperando desenlaces sempre adiados, embora todo o tempo insinuados: miséria, doença e finalmente a morte. Uma sofisticada articulação de uma estrutura que cerca, oprime e sufoca, surgindo dos enredos, das falas e dos estados mentais das personagens.

Daí o sentido crítico que pretende o autor: não há qualquer possibilidade de pensamento otimista ou afirmativo em relação aos rumos da modernização brasileira desigual e incompleta. Revela-se uma ácida desconfiança do presente e um desalento sem remissão no que concerne o futuro, daí brotando um acentuado sentido do trágico. Essa tragicidade advém do tom sombrio de mundo abandonado por Deus, em que não há exatamente bons ou maus, culpados ou inocentes, nem heróis ou anti-heróis, mas seres humanos iguais na mesma miséria e no mesmo destino, infligido por circunstâncias muito acima de sua compreensão.

\section{Fábulas}

Os romances de Ruffato, em geral, dialogam entre si em Inferno provisório, reafirmando que as questões históricas e sociais não têm apenas uma relação com os textos, elas os constituem e lhes dão forma. A organização formal de "A expiação", acima citada, longa história vazada em um realismo violento, cruel ou feroz - seja qual for o termo empregado para se referir a um aspecto comum na ficção contemporânea - corresponde às especificidades do processo de formação de um Brasil, que se rearticula no texto ficcional.

O último capítulo da obra chama-se "Outra fábula" (Ruffato, 2016, p. 387-404), uma espécie de resumo de tudo o que foi narrado ao longo do livro, uma síntese dos caminhos percorridos pelos muitos personagens que fugiram de um quotidiano previsível e claustrofóbico, aglutinados na memória dos "quarenta anos cumpridos" (Ruffato, 2016, p. 387) da vida de um deles, Luís Augusto. Uma espécie de fluxo de consciência em flashback envolve o leitor em uma enxurrada de fragmentos antes espalhados aleatoriamente por quatro décadas e tantos capítulos, agora organizados em um continuum cronológico e ordenado, juntando finalmente os dias, lugares e pessoas, desaguando no presente da narração. As décadas desfilam, refazendo agora a cronologia que Ruffato desde o início propositalmente desfez: 
Imerso entre os milhares de calções e camisetas numeradas, sob um calor de mais de trinta graus, aguardando o sinal para o início da largada da Corrida de São Silvestre, na tarde do último dia de 2002, tudo, tudo isso Luís Augusto buscava esquecer (Ruffato, 2016, p. 404).

Interessante notar que, neste final, a derrota existe apenas como sombra de um destino antes traçado que, para Luís Augusto, não se cumpriu. Sob o céu escaldante de São Paulo, ele rememora seu passado, desde o dia em que finalmente resolvera fugir de Cataguazes: "Mãe, vou embora pra São Paulo" (Ruffato, 2016, p. 390). A mãe desespera, o pai consola: "Que bobagem, ô, Jânua, queria o quê?, que o menino ficasse aqui, capacho dos Prata? [...] São Paulo é um mundo..." (Ruffato, 2016, p. 391). Rememora seus esforços para não voltar acabrunhado de saudade: "se operária sua involuntária ascendência, outra seria sua posteridade" (Ruffato, 2016, p. 394). "E se recuasse trinta anos? Um menino tímido, pasmado, esquadrinhando as ruas de Cataguases, nos braços um tabuleiro de alumínio coberto por um alvo pano de prato, pasteis, coxinhas, rissoles..." (Ruffato, 2016, p. 388). "Rememorou-se adolescente, rosto destruído pela acne, tímido e arredio" (Ruffato, 2016, p. 393); rememorou os olhos castanhos de Lívia entre "os mais de um milhão e meio de cabeças que, numa noite de abril de 1984, inundaram o Vale do Anhangabaú exigindo o fim da ditadura e eleições diretas já" (Ruffato, 2016, p. 404); rememorou as mortes de pai e mãe, lembrou o irmão bêbado, a irmã desquitada, "as corredeiras impacientes do rio Pomba..." (Ruffato, 2016, p. 391). E, esperando a largada, Luís Augusto “especulava se conseguiria vencer os quinze quilômetros de subidas e descidas do trajeto" (Ruffato, 2016, p. 387). Parece emergir aí, tímida, uma perspectiva de esperança para um futuro que se abre, desconhecido, na entrada do ano de 2002. "Outra fábula" (ironia?) é o ponto de chegada de uma corrida que se iniciou também com "Uma fábula", gênero literário de caráter moral e ético, narrativa de sentido fantasioso, mais de quatrocentas páginas atrás. ${ }^{7}$

Há, nessa junção de pseudofábulas, uma no início e outra no fim da obra, como duas pontas de um novelo emaranhado, um aspecto que parece negar o sentido realista de todo o romance, ativando a sensibilidade do leitor, perturbando-o, fazendo-o hesitar, perplexo, envolvendo-o na ficção, mas de fato aguçando sua percepção da realidade da matéria de que partiu essa ficção. A cumplicidade do leitor, nesse processo, está implícita no próprio conceito de realismo aqui utilizado, pois este é uma prática que atribui sentidos à vida social, é sua tradução estética, sendo que nessa compreensão sempre estarão envolvidos autor e leitor. Tal envolvimento resulta de que a literatura tem uma dependência implícita ou explícita em relação às coletividades humanas de que surge e sua capacidade de representação é justamente o lugar em que a vida real, com toda sua complexidade social e subjetiva, nela se entranha. É nesse ponto que se encaixa o entendimento das posturas e métodos referentes à tomada de posição diante de realidades específicas e a observação crítica muito próxima do que é real ou tomado como real.

Em Inferno provisório, do cortiço ao beco, vielas, periferias e avenidas, do rural ao urbano, da ditadura à democracia, do antigo ao moderno, da construção à ruina, o método de Ruffato encarna claramente uma postura crítica negativa, ética e política em que, na melhor acepção realista, segundo Williams:

Cada aspecto da vida pessoal é radicalmente afetado pela qualidade da vida geral, mas a vida geral, no seu âmago, é totalmente vista em termos pessoais. Em todos os sentidos, cada aspecto da vida geral é valorizado, mas o centro dessa valorização é sempre a pessoa humana - não um indivíduo isolado, mas as muitas pessoas que formam a realidade da vida geral (2001, p. 304-305).

\footnotetext{
${ }^{6}$ Em vista das muitas declarações públicas do autor, em tantos veículos da imprensa, é possível pensar que ele escolheu uma data histórica real neste ponto: a eleição de Luís Inácio Lula da Silva para Presidente do Brasil, que se deu em dois turnos, a 6 de outubro de 2002 e 27 do mesmo mês e que abriu um período de esperança para o futuro do país.

7 “Inferno provisório termina no dia 31 de dezembro de 2002, na corrida de São Silvestre, porque eu pensava que estávamos todos correndo na mesma direção. Mas será que estávamos mesmo?” (Ruffato, 2019).
} 


\section{Referências}

ADORNO, Theodor W. (2003). Posição do narrador no romance contemporâneo. In: ADORNO, Theodor W. Notas de Literatura I. São Paulo: Duas cidades; Editora 34. p. 55-63.

ANDERSON, Benedict (2008). Comunidades imaginadas. São Paulo: Companhia das Letras.

AUERBACH, Eric (1976). Mimesis. São Paulo: Perspectiva.

AZEVEDO, Aluísio (1999). O cortiço. São Paulo: Moderna.

BOURDIEU, Pierre (1966). A força da representação. In: BOURDIEU, Pierre. A economia das trocas linguísticas: o que falar quer dizer. São Paulo: Edusp. p. 107-116.

CANDIDO, Antonio (1995). De cortiço a cortiço. In: CANDIDO, Antonio. O discurso e a cidade. São Paulo: Duas Cidades. p. 123-152.

CANDIDO, Antonio (2010). Os parceiros do Rio Bonito. Rio de Janeiro: Ouro Sobre Azul.

DEALTRY, Giovanna (2009). Cidades em ruínas: a história a contrapelo em Inferno Provisório, de Luiz Ruffato. Estudos de Literatura Brasileira Contemporânea, Brasília, n. 34, p. 209-221, jul./dez.

HARRISON, Marguerite Itamar (2007). Uma cidade em camadas: ensaios sobre o romance Eles eram muitos cavalos, de Luiz Ruffato. Vinhedo: Horizonte.

OLIVEIRA, Marcus Vinicius Ferreira (2017). A ruína e a máscara: as contradições de uma modernização conservadora. Tese (Doutorado em Letras) - Universidade Federal de Juiz de Fora, Juiz de Fora. Disponível em: https:/ / bit.ly/35rRjnM. Acesso em: 23 jun. 2019.

PELLEGRINI, Tânia (2018). Realismo e realidade: um modo de ver o Brasil. São Paulo: Alameda.

RANCIÈRE, Jacques (2014). A política da ficção. Lisboa: Ed. J. F. Figueira e V. Silva.

RUFFATO, Luiz (2006). Literatura com projeto. Entrevista concedida a Heloisa Buarque de Hollanda e Ana Ligia Matos. Z Cultural, Rio de Janeiro, ano 3, n 1, 10 mar. Disponível em: https://bit.ly/2rYWDS6. Acesso em: 14 jan. 2019.

RUFFATO, Luiz (2016). Inferno provisório. São Paulo: Companhia das Letras.

RUFFATO, Luiz (2019). Novo romance de Luiz Ruffato retrata falta de diálogo entre as classes sociais no Brasil. Entrevista concedida a Ruan de Souza Gabriel. O Globo, Rio de Janeiro, 8 maio. Disponível em: https://glo.bo/36pqmCL. Acesso em: 22 maio 2019.

SCHØLLHAMMER, Karl Erik (2016). Um mundo de papel: reflexões sobre o realismo de Ruffato. Alea, Rio de Janeiro, v. 18, n. 2, p. 232-242.

SOARES, Raoni Damiano (2017). Recordação e esquecimento em Inferno Provisório: Mamma, son tanto Felice, de Luiz Ruffato. Dissertação (Mestrado em Letras) - Universidade Federal de Ouro Preto, Mariana. Disponível em: https:/ / bit.ly/2tsPx8I. Acesso em: 23 jun. 2019.

VETORASSI, Andrea (2018). Laços de trabalho, fios da memória e redes migratórias. Curitiba: Appris.

WILLIAMS, Raymond (2001). The long revolution. New York: Broadview Press. 